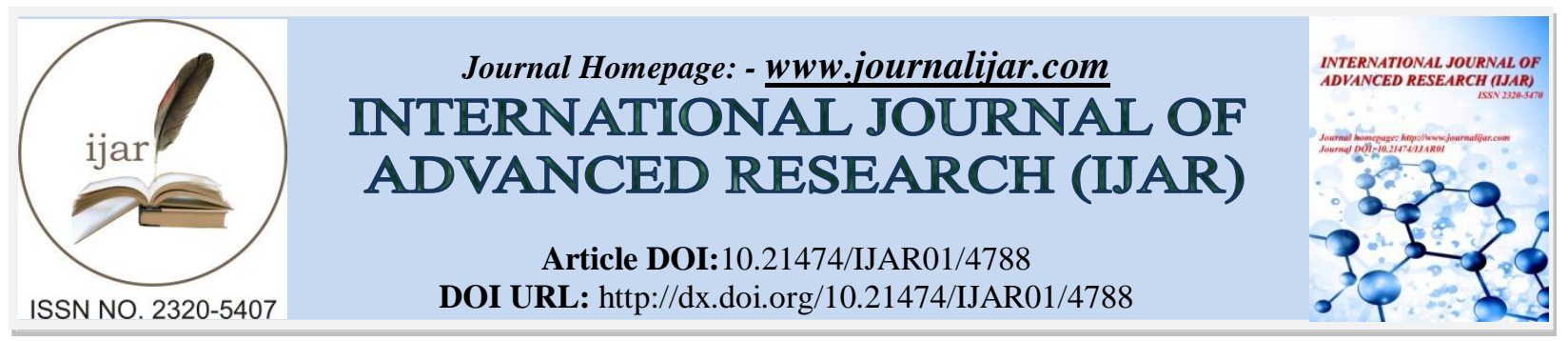

RESEARCH ARTICLE

\title{
CRIMES AGAINST SEXUAL FREEDOM AND MORALITY AT THE APPELLATE COURT AREA OF STIP.
}

Aleksandar Trenevski.

\section{Manuscript Info}

(.........................

\section{Manuscript History}

Received: 8 May 2017

Final Accepted: 10 June 2017

Published: July 2017

Key words:-

felony, rape, legislation, sexual freedom, morality

\section{Abstract}

If crimes against sexual freedom and morality, as an important issue of a specific region or country, are taken into account it would enable us to seriously understand the problem which carries the crime itself. This would provoke the start of an appropriate treatment for prevention of this type of crime with the aim of helping the victims overcome the survived traumatic events much easier. The criminal legal protection of sexual freedom and morality is provided by the Criminal Code of the Republic of Macedonia, in Chapter XIX (article.186 to 194). The prevention and reduction of the number of crimes against sexual freedom and morality, and the provision of funds for the implementation of assistance and protection of sexually abused people as well as the establishment and promotion of a coordinated system of cooperation between the competent institutions and local authorities of the Shtip's appellate region, including all the areas that cover this issue partially or completely inevitable. The goal is to take prevention measures and sensibilise the general public about these negative phenomena.

The restriction of sexual freedom leads to humiliation and violation of the victim's dignity and violation of human freedom and human morality that can leave permanent consequences which can be even fatal for the victim.

Individual characteristics of the offenders indicate that they are uneducated, single, with no property and are alcohol addicts. The proportional representation of crimes against sexual freedom and morality in the Stip appellate region in proportion to the overall representation of this crime at the level of the Republic of Macedonia indicates that in this area the number of such crimes is very small compared to the total number of sex crimes in the Republic of Macedonia.

Copy Right, IJAR, 2017,. All rights reserved.

\section{Introduction:-}

Links between sex and crime are deep, permanent and paradoxical. Ever since the monitoring of the performance of the transgression, it has been noticed that men and women differ in rates of violations and patterns of criminal behavior, as well as in bullying experiences. Besides, the comprehensive data resulting from this situation significantly affect forensic opinion and the politics of criminal justice. The criminal protection of a woman in the area of sexual delicts is accomplished by prescribing criminal offenses, considering the biological (anatomical) 
characteristics of the woman and taking into account their definition in most of the modern criminal laws, can be committed exclusively to the detriment of the woman and crimes that can be committed both to the detriment of the woman, and to the detriment of the man, but with rare exceptions, they are mainly carried out against women.

All criminal laws in modern societies anticipate these crimes and their essence is the same. Such criminal legal protection is given by our legislator with the incriminations of Chapter XIX of the Criminal Code (criminal offenses against sexual freedom and sexual morality). Satisfying the agent's sex drive is a common characteristic of these offences. Group protected object of these offences may be endangered by sexual intercourse, other sexual acts and many other activities. These actions assault on the person's sexual freedom, exploitation of disabled persons and abuse of certain relationships in order to satisfy the sexual urge or are undertaken on minors with the same goal. According to the Criminal Code of Macedonia it is important to say that sexual acts between adults enter the penalty area when they are committed by force, or by using the state of vulnerability or abuse of position, whereas children's sexual integrity and their unhindered sexual development are protected much more significantly by the legislator. Protection of persons under the age of fourteen is absolute regardless of the type of sexual act, sex of the child and his eventual consent and initiative. If these activities are committed to an adult victim under punishable circumstances, their individual importance is emphasized with greater penalties than those laid down in the punishable acts committed against an adult. With the description of the crime satisfying sexual urges in front of a child this protection has been extended in sexual acts in which there isn't a physical contact between the offender and the child.

Criminal protection of 14 to 18 year olds is somewhat narrower. The sexual offenses in which the victim is a person at this age are normally punished only in cases punishable for adults. The legislator provides extended protection of these sexual acts for a particular category of minors, regardless of their gender, who are in a special subordinated relationship to the offender. Irrespective of their consent, minors are also protected and even initiative for sexual acts of adult offenders in a homosexual relationship.

Rape is the basic act in the group of offenses against the person's dignity and moral. Sex drive with its various forms of expression could significantly jeopardize certain social values. Disruption of the individual's sex drive can be expressed in quantitative and qualitative direction. In quantitative terms disorders of sexual desire are disorders in expressing the intensity of sex drive. For the conditioning of criminal behavior cases of impotence and hyper potency are of great significance. However, qualitative disorders have greater significance for criminology. They have two forms. Targeting the satisfaction of sexual desire towards persons of the same sex being the first form, and the second is expressed through sexual perversions. It involves several types of sexual disorders: pedophilia, gerontophily, sodomy, pyromancy, necrophilia, fetishism, transfetishism, exhibitionism, sadism, masochism, etc.In this case it is a characteristic that most of the applicable criminal laws in the world with the prescription of the crime as a rape of a woman provide criminal legal protection from sexual violence committed against her by a man with who she does not live in a marital union. However, recently there has been a trend of spreading criminal protection even in cases of so called Marital rape. Violence should be condemned regardless of the existence or non-existence of marriage. Marriage cannot be an alibi for violence. That fact that such violence will not be easily proved and that it can be misused are not sufficient reasons for deviating from the much more important principle standpoint: that human freedom, including the right to sexual integrity is an important value that requires full protection even in marriage.

\section{Crimes against sexual freedom and Morality:-}

Crime is a central category in the system of criminal law. It legitimizes the right of punishment and determines the range of criminal law repression and from its term other main categories are derived: criminal responsibility (for a certain offense) and punishment (as a fair response to the crime committed). On one hand we talk about crime as a legal type illegally, but on the other hand as a real crime event whose features match the formal, abstract type of prohibited conduct.Besides the general criminal-political significance, for the system of categorization of the criminal law it is important that its definition as a basic and generic term summarizes the content of all the objective and subjective, formal and material elements of the offense as a legal, as well as a real phenomenon. The notion of crime also involves the perpetrator, the author of the act who by his action had made an improper legal type. Accordingly, the offense is an unlawful act which by law is defined as a crime, and whose characteristics are determined by law.According to this approach the legislator has the exclusive competence to assess the behavior as prohibited and while determining the forbidden according to the principle of legitimacy he must follow the civilized base on prohibitions and to declare as criminal actions only those behaviors that represent serious violation or threat 
to human rights and the common features of life. In accordance with the fundamental principle of legality, offence is just the behavior that is explicitly prohibited by law.

No matter how harmful a behavior is, or violates important values and goods (smoking, alcoholism etc.), it remains within the frame of socially - negative behavior until it is raised to the level of behavior prohibited by law. The legislator declares a certain behavior as an offense if it is a socially dangerous behavior for man.

\section{Perpetrator of a Crime:-}

A perpetrator of a crime is an active entity, i.e. with his action is accomplished the legal essence of the act. In practice when we talk about a perpetrator we always talk about an individual. The perpetrator is the immediate executor of the crime, but in some cases there are others involved in its execution. An active subject of an offense can be any individual who is able to undertake certain actions regardless of gender or age.

According to the legal provision all persons who are over fourteen years of age may occur as potential offenders. It is not ruled out that a crime can be carried out by a juvenile under the age of fourteen, but this offender is not subjected to any criminal legal sanction. In determining the perpetrator computability or incommutability are of great importance. An "executor" of a crime is the individual who performs the action by himself and for which punishment is expected with all the objective and subjective characteristics of the case.

\section{Victim of a Crime:-}

Victim of a crime is any person who has suffered harm, including physical or mental injury, emotional suffering, material loss or other injury or violation of their rights and interests as a result of a crime. The offense cannot be completely clarified if only the crime genesis of the offender is being investigated, but also the injured party should be studied as well, i.e. why a person became a victim of a bully or sexual delinquent. Through the study of the victim's characteristics the victim's genesis is also being investigated.

In sexual offenses victims and their characteristics play an important role in the conditioning of the crime. Thus in this area of criminal conduct worthy space is acclaimed to the victim's characteristics particularly if it's a crime of rape or sexual abuse of children. Recent studies in the crime of rape show that the most frequent victims of this act are people aged 18 to 25 , whereas the number of older victims is sharply declining. With married victims it is noticed that the criminal complaint for rape is justified with frequent absence from home or relationship with other men. For those aged 40-50, complaints often arise because of the period of menopause which is associated with the accumulation of charges and false accusations. Generally speaking, a crime of rape often turns out to be false.

\section{Research by the Appellate Court Stip:-}

The degree of criminality in the Republic of Macedonia is affected by the setting of the regulatory framework and the implementation of laws. In the context of what is written so far we come to the primary purpose of this paper, it is an investigation of cases derived from the Appeals Court Stip, relating to crimes against sexual freedom and morality. These are crimes that are found in Chapter XIX of the criminal Code of Macedonia.

Through the elaboration of second instance judgments we learn about the prevalence of this crime, the ways of execution, how high the fines imposed on offenders are, the treatment of victims, the way of conducting the procedure etc. By presenting the verdicts in this way an opportunity to individually consider the sanctions provided in the Criminal Code is offered The survey covers the period from 2012 to 2015 and particularly in the area of Stip.

The purpose of this research is to be more precise about what crimes we talk about, how serious they are and are the perpetrators appropriately and correctly treated, as well as how are victims, whose justice must be satisfied, treated. By punishing the perpetrators it is intended to deter them from reoffending and it also represents a social revenge for the crime committed, in other words, punishing the offender for his criminal behavior that violated the law and order in the society and at the same time caused greater or lesser damage to another person. According to the nature of these crimes it can be said that the overall rate of all crimes on the territory of the Republic of Macedonia has a quite small percentage compared to the total serious crimes envisaged in the Criminal Code. The confidentiality of the data makes these cases difficult to access and the content itself and the protection of honor and dignity when it comes to the victim of this crime. 


\section{Statistical Review of crimes against sexual freedom and Morality:-}

The statistical data that will be presented refer to reported, accused and convicted adult and juvenile perpetrators of criminal acts against sexual freedom and morality in the period from 2012 to 2015 . These data are the result of a regular, annual research and provide reliable information to all perpetrators of crimes in the Republic of Macedonia.

Information contained in these statistics applies to all stages from filing a charge till the judgment becomes final. Data source: the State Statistical Office and the Court of Appeal - Stip. The State Statistical Office bases judicial statistics on regular surveys and data collection from the Primary and Appellate courts in the Republic of Macedonia and apply to all crimes.

Public prosecutors and the courts answer pre prepared questionnaires and then the State Statistical Office does the full summarizing and processing of the data. Overall the data is reliable and relevant to all segments of the judiciary from filing charges until the sentence becomes final, acquittal, lifting etc. Data on accused adults apply to all persons against whom the criminal proceedings on indictment, an indictment and a private lawsuit are legally completed in the year concerned.

\section{Development of Hypotheses:-}

Whenever we focus just on sexual freedom and morality there is an impression as if we are talking about a taboo subject that has already taken a large scale, but still those stereotypes, that have always existed, cannot be overcome and it is a shame to talk about such topics kept in secret as long as possible by people and even more by institutions. The difficult access to information and the confidentiality of the information contained in these kinds of crimes, results in lack of awareness of the population, and thus people don't know how to act in such criminal cases.

The group of offenses against sexual freedom and morality includes serious crimes for which imprisonment from one year up to life imprisonment is prescribed, depending on the type of the act, the way of commitment and the severity of the consequences. The primary goal of all that is presented in this paper offers an opportunity to show in detail all kinds of crimes in Chapter XIX of the Criminal Code of the Republic of Macedonia, the way of committing the crime, the people who carry out the crimes, their characteristics, the people upon whom these crimes are committed as well as their characteristics and traits and the kinds of consequences.

With the help of the hypotheses and the order of their proof or rejection we come to a conclusion whether recent amendments to the law have reduced the percentage of such crimes over the years and is social awareness for serious crimes in this area raised to a higher level. For this purpose cases from the everyday practice of the Appellate Court in Stip have been used and the overall statistics from the National Bureau of Statistics of the Republic of Macedonia have been taken for comparison.

The total number of offenses against sexual freedom and morality of the Appellate Court in Stip is 46 for the period from 2012 to 2015. Of all these cases 14 are for the crime of rape by article 186, 4 for the offense of rape of a helpless person of art. 187, 12 for the crime of sexual assault on a minor under 14 years of age of art.188, 1 for the offense of abuse of official position and authority of art.189, 7 for satisfying sexual urges in front of another art.190, 2 for procuring and enabling sexual acts of art. 192, 3 for showing pornographic material to a minor of art.193 and 3 of incest of art .194, while by article 191 mediation in prostitution has not been registered in the relevant period.

Of the total 14 cases of rape by Article 186, 5 cases were confirmed and imposed imprisonment from 6 months up to 10 years. Repealed 4, rejected 2, 1 is stopped, 1 is reversed and 1 case is in concurrence to cases by Articles 188, 190, 193 are being added. Statutory rape of a helpless person by article 187 is represented by 4 cases of which 2 are confirmed, one is in concurrence to case by art. 188, and for one case treatment in an appropriate institution is being judged. The case of sexual assault on a minor under 14 years by Article 188 is present in 12 cases, of which 4 have been confirmed, 2 suspended, 3 were rejected, 1 is altered, 1 released and 1 has not been solved yet. The crime of sexual intercourse by abuse of position by Article 189 is present only in 1 case and is confirmed.

Satisfying sexual passions in front of somebody else by Article 190 is present in 7 cases, of which in 5 a suspended sentence is being imposed and for 2 cases only a prison sentence is pronounced. 
The act of procuring and enabling sexual acts by Article 192 is present in 2 cases and for both jail sentences were awarded- in one of the cases where 2 persons took part one of them was sentenced to 5 years in prison and the other to 3 years.

Showing pornographic materials to a minor by art.193 is present in 3 cases, one of which has been confirmed, 1 is released and 1 is modified in case by Article 188 .

The case of incest by Article 194 is present in 3 cases, all of which are confirmed, and 1 of them is in concurrence and for which a penalty of 19 years of imprisonment is imposed.

In the context of the already mentioned research from the Stip area, data received from the whole territory of the Republic of Macedonia will be presented below, so that later you get the exact dimensions of the representation of crimes against sexual freedom and morality.

According to statistics from the National Bureau of Statistics in 2012 -109 cases are reported, in 2013- 108 cases, in 2014- 88 cases and in 2015- 74 cases. In 2012 from the reported 109- 54 were accused, 47 were convicted, in 2013 of the 108 reported 78 were accused and 64 were sentenced, in 2014 of the 88 registered 65 were accused, 49 were convicted, in $2015-74$ were reported of which 60 were accused and 56 were sentenced.

Of all these cases, 23 were for rape, 17 of which were sentenced to prison, 16 cases for sexual assault on a child under 14 years, 12 of them were imprisoned, 7 cases for mediation in prostitution, of which only 1 was sentenced to prison and there are other 28 reported cases in procedure, 11 sentenced to prison. All of these reported cases do not end with charges i.e. for some of them the application had been rejected, such cases are 15, in 2 cases the investigation is stopped and only in 54 cases indictment has been released. According to this data presented out of 379 reported cases for the period from 2012 to 2015, the Appellate Court in Stip participated in 46 cases which in general is not a large number of representations.

Due to drastic changes in increasing the punishment for certain crimes in this area the number of reported offences has notably reduced, for ex. from 108 reported crimes in 2013 there were only 88 in 2014 and 74 in 2015. The main goal has been reached or in other words the proportional increase of the sentence reduced the crime. It is necessary to note that all these numbers of crimes do not end in charges or convictions, some of them are rejected, some are modified, and some are repealed as unfounded or because of lack of credible evidence and the like. The fact that every person is born free, independent of others' will is known worldwide and each country, including the Republic of Macedonia, guarantees these freedoms and rights. When it comes to human rights, the right to consent to sexual relations on one's own will and without coercion, blackmail or threat occupies one of the main places.

\section{References:-}

1. ВладоКамбовски (2005): КазненоПраво - Општдел

2. ВладоКамбовски, НиколаТупанчески (2011): КазненоПраво - Посебендел

3. ЈоханесВеселс, ВернерБојлке (2009): Кривичноправо - Општдел

4. ФренсисХејденсон, ЛоренГелсторп: Половите и криминалот

5. КаролинХојл, ЛуцијаЗеднер: Жртви, виктимизација и кривичнаправда

6. ОлгаКошевалиска (2013): СкриптаКазненоправо - применетапрограма

7. Камбовски, В (1997): Казненоправопосебендел, Просветнодело, Скопје

8. Камбовски, В (2004): Казненоправо, Општдел, Култура, Скопје

9. Камбовски, Б (2011): КоментарнакривичензаконикнаРепубликаМакедонија - интегралентекст, КлубМатица

10. Камбовски и др.,Одмерувањенаказнатавозаконскирамки, МРКК, бр.2 - 3, 2008, стр.235-278.

11. Марјановиќ, Ѓ. (1998): Кривичноправо - Општдел, НИО Студентскизбор

12. МатовскиНикола, ГорданаЛажетиќ - Бужаровска, ГорданаКалајџиев, - Казненопроцесноправо, Правенфакултет ,јустинијанПрви“ - Скопје, 2009

13. Матовски, Лажетиќ-Бужаровска, Калајџиев - Казненопроцесноправо, Второизменето и дополнетоиздание, Скопје, 2011

14. Мисоски Б

Б., $\quad$ Груевска-Дракулевски,

A. (2014):Компаративнаанализанамеханизмитенаупатствазаодмерувањеказна:

Упатстозаодмерувањеказнаво САД, МРКПК стр.91-111 
15. Неделкова Л. (2014): ОсвртнаправилникотзаначинотнаОдмерувањенаказните, МРКПК, стр.13-33

16. Тумановски А. (2014): КазненаполитиканасудовитевоРепубликаМакедонија одмерувањенаказнатасогласноизменитенаКривичниотзаконикод 2014 година

17. Шкулиђ М. (2010): Кривично процесно право, Другоимењено и допуњеноиздање, Београд

18. Новоселац П. (2007) ПосебнидеоКазненогправа - првоиздање, ПравнифакултетСвеучилишта у Загребу

19. Миладиновиђ-Стефановиђ Д. (2014): Хемиска Кастрација - Прихватљиво средство за спречавање кривичних дела против полне слободе према малолетницима? Зборник Радова Правног Факултета у Нишу, Број 66, pp.51'68

20. Констатиновиђ - Вилиђ, С. Николиђ Ристановиђ, В., Костиђ, М. (2009) Криминологија, Ниш: Пеликан принт

21. Закон за малолетничка правда („Службен весник на Република Македонија“, бр.87 од 12 јули 2007)

22. Закон за судовите (Сл. Весник на РМ бр. 58/2006, 62/2006, 35/2008 и 150/2010

23. Закон за кривична постапка, Службен весник на РМ бр.150.2010

24. Закон за изменување на Кривичниот законик, Службен весник на РМ бр. 28/2014

25. ГРуевска-Дракулевски, А. (2011): Казнената политика на судовите во Република Македонија во периодот 2007-2011

26. Гогов Б. (2014): Реформа а казнената политика или нешто друго МРКПК

27. 27.Главинче Н.(2015): ОчекуванитеимпликацииоддонесувањетонаЗаконотзаопределувањенавидот и одмерувањенависинатанаказнатавопрактика, СтручносписаниеПравилник, бр.276, април

28. Бужаровска-Лажетиќ Г. (2014): Проблемиказненеполитике у оквируспоразумевање о кривичнојсанкции у РепублициМакедонији, Казненаполитикакаоинструментдржавнаполитикакриминалитета, БањаЛука

29. Бужаровска-Лажетиќ Г., Тупанчески Н. (2015): ПарадоксотнаМакедонскотоЗаконодавство, СтручносписаниеПравилник бр.286

30. БрашерТајд Л. (2012):Анализанамакедонскатаказненаполитика и препоракизанејзиниотиденразвој: Конпоеднообразенсистем, ОБСЕ МисијавоСкопје

31. Билтеннаапелационисудовипогодини и градови, достапнина:http://www.pravdiko.mk/bilteni-so-presudi-izakluchotsi-na-apelatsionite-sudovi/

32. .Бачановиќ О. Полицискаакадемија - Скопје, Университет „Св. КлиментОхридски“ - Битола, Кривилноправназаштитанамалолетнилица - жртвинакривичнидела

33. Арнаудовски Љ. (2014): Казненаполитика, КРКПК, стр.43, Судскиделовник, Службенвесникна РМ бр.66/13

34. Крапац Д. (2010): КазненопроцеснпавоПрвакњига: Институције, IV имењено и допуњеноиздање, Загреб

35. Кривичензаконик („СлужбенвесникнаРепубликаМакедонија“ бр. 37/1996, 80/1999, 4/2002, 43/2003, 19/2004, 81/2005, 60/2006, 73/2006, 7/2008, 139/2008, 114/2009, 51,2011, 135/2011, 185/2011, 142/2012, 166/2012, 55/2013, 82/2013, 14/2014, 27/2014, 28/2014, 115/2014, 132/2014, 160/2014 и 199/2014) ОдлукинаУставниотсуднаРепубликаМакедонија: У.бр.220/2000 од 30 мај 2001 год., објанебво „Службенвесникна РМ“ бр. 48/2001; У.бр. 210/2001 од 6 февруари 2002 год., објавенаво „Службенвесникна РМ“ бр. 16/2002; У.бр. 206/2003 од 9 јуни 2004 год., објавенаво „Службенвесникна РM“ бр. 50/2006

36. Taylor M., Quayle E: Child Pornography An Internet Crime, Brunner - Routledge, 2003, New York

37. Soothill K., Harman j., Francis B., Kirby s., (2005): identifuing future repeat danger from sexual offenders against children: a focus of those convicted and those strongly suspected of such crime. Journal of Forensic Psychiatry and Psyhology, vol.16, no.2 p.225-247

38. Patrick S. Marsh R. (2009): Recidivism among Child Sexual Abusers: Initial Results of a 13-year Longitudinari Random Sample. Journal of Child Sexual Abuse, p.123-136

39. Orthman J (1980): The Treatment of Sexual Offenders, In International Journal of Law and Psychiatry

40. Law for special measures for the prevention of criminal act against the sexual integrity of minors, Official Gazzate of Serbia No. 32/13

41. Gibbons Thomas (1996): “Computer Generated Pornography” International Yearbook of Law Computers and Technology, 1995, vol. 9 pp83-95 p.87 